\title{
International Journal of Management
}

Science and Business Administration

Volume 1, Issue 5, April 2015, Pages 81-89

\section{Strategies and Determinants of Foreign Direct Investment (FDI) Attraction}

\author{
Abdoulaye Oury Bah, Xie Kefan, Oji-Okoro Izuchukwu \\ School of Management and School of Economics, Wuhan University of Technology, Wuhan, P.R.China \\ Corresponding author (e-mail): bahgio2008@hotmail.com
}

\begin{abstract}
The globalization of the world economy has created enormous opportunities as well as promotion efforts to attract foreign direct investment (FDI). The goal of this study is to detect and analyze management strategy to attract foreign direct investment. We conduct a detailed literature review and identify different strategies for capital issues and benefits of FDI. There are several trends that drive FDI like availability of natural resources, cheap labor markets and low cost which must be considered in order to take appropriate measures to attract more investments. The main contribution of the study is that it builds a theoretical basis which is useful for managers, entrepreneurs and decision-makers to make rational decisions on the choice of location for investments.
\end{abstract}

Keywords: Foreign Direct Investment, FDI, FDI Attraction, FDI Strategy and Determinants, IDE

\section{Introduction}

Foreign investment flows are driven not only through the host country capital, but also through attempts to acquire technology and know-how and to access to new markets (Papanicolaou, Booth, and Neumeier, 2010) as well as to achieve profits (Booth, Königer, and Nunnenkamp, 2010; Kumar and Siddharthan, 2013). FDI helps to solve several problems; it provides valuable capital to stimulate economic growth and development and it transfers technology and knowledge. Additionally, it enables access to foreign markets. In fact, knowledge and workforce skills as well as productivity aspects have a significant impact in attracting and retaining foreign direct investment (Monaghan, 2012),. Most countries in the world are now trying to attract and facilitate international investment. Currently, following economic integration policy, governments continue to implement policies, investment strategies and actions to ensure that engine of the real economic 
development in the industrial sector keeps working. Technology transfer from foreign direct investments has an undeniable role for developing countries. Promoting market access and network building between regional and global production brings transfer of knowledge and technology as well as faster introduction and diffusion of new technologies, thus enabling the host country to build technical and organizational capacity (Kumar, 1998; 2009). Technology transfer also enhances the development of local technical capacity and facilitates modernization. Interactive development environment allows the diffusion of technological innovation; helps in development and attaining high-tech products and promotes cultural exchange between countries. Musolesi (2006) aims to determine the different stocks of knowledge, including the true magnitude of the relationship between the "foreign" in passing and total trade flows productivity between countries. His conclusion is that affirmative action in public research and academic research results in a direct investment in the country.

The concept of this study has been designed for a more specific analysis of FDI contribution to socioeconomic and technological development. Indicators like formation of a broader strategy and measures to improve macroeconomic conditions, personnel skills, and infrastructure serve to promote enterprise development. For all these measures to be more visible and tangible FDI is very important and countries need to know good use of it. Interactive development environment also implies political decisions for foreign direct investment. Friendly political environment increases the attractiveness of the host country for international FDI. Some important political aspect of interactive development environment of the host country is removal of different legislative-bureaucratic barriers for foreign investors, creation of transparent regulations on foreign direct investment as well as proficiency of legislative services to protect the rights of investors available at host countries. FDI helps to eliminate geographic restrictions on expansion or merger or barriers, with the competition leading to a deepening of the company or coordination of competition policy (Bevan and Estrin, 2004).

\section{Foreign Direct Investment: Trends and strategies}

Investor's objective in bringing direct investment is to reap profits (UNCTAD, 2012). There is a significant trend with a flow of foreign direct investment in recent years according to UNCTAD; there are two main ones. First, the amount of foreign direct investment is decreasing in developed countries and moving to developing countries contributing to its increase. As UNCTAD data shows (UNCTAD, 2012), China is now cited as a favorite destination country for investments. Another important trend in global investment report is that efforts by countries to promote foreign investment doubled; global financial crisis occurred in 2008 led to this intensification. In fact, turmoil in financial markets, uncertain outlook for future economic growth has made many countries promote foreign investment to support economic growth and development (UNCTAD, 2012). The problem of FDI location is studied from the perspective of multinational companies. According to Dunning (1998), the choice of location is determined by a variety of factor also taking the objectives of the company into account. For example, one company may be looking for productivity gains or 
reduced costs. Attracting multinationals is based mainly on the ability to enhance competitive edge accordingly (Porter Company, 1990; 1998; 1985). More specifically, factors such as transport and communications networks (physical infrastructure), skilled labor (human factor) and learning opportunities backed by the presence of the stream of knowledge are crucial in selecting a location. Note that these are the main elements of the environment. McCann and Mudambi (2004) consider the Porter's perspective of OLI (ownership, localization and internationalization). Basically, research in international management can be obtained through the integration of new initiatives or expert perspectives on regional development and economic geography. Monaghan (2012) emphasizes the importance of local organizations in attracting foreign direct investment network. According to Ireland (2008), different actors play different roles in attracting FDI; they are sub-region, regional as well as national entities such as regional development agencies, educational institutions, private service providers, chambers of commerce and others.

Interestingly, according to some researchers (Sinanagic, Civic, and Kamaric, 2012), actions taken by government agencies to improve home environment to minimum international standards results in attraction of more foreign direct investment. To improve country's image for a good business environment and a good place for FDI various actors need to be taken into consideration. In this sense, especially in developing countries, public money should be first used to improve infrastructure, to reduce corruption, to develop corporate finance, to educate people and prepare knowledgeable and skillful workers rather than trying to promote the country by marketing and struggling for creating advertising campaigns for this. Confirming this idea, Brossard (1998) also empirically proves that although OIP (Investment Promotion Organization) has an essential role in foreign direct investment, it is anyway not a significant factor to give a priority. More specifically, the information and data services based on the key location provided by the OIP offer the most for investor needs and it was discovered that small investors also support the staff. According to Mucchielli (1998), FDI strategy proposed is the use of different countries to attract national institutions and to promote investment. According to the author, these institutions have three objectives: to improve the image of the host country in the international investment community;Access local and foreign investors; provide a range of services like hospitality for potential investors and effective capacity building. To achieve these objectives, variety of media, advertising, trade fairs, tele-marketing should be approached and implementation process should be well monitored. On this issue, Kalamova and Conrad (2010) found that difference between actual picture of a country and a stereotype about the country also has impact on foreign direct investment flows. Stereotype cited as "Excellent German quality" emphasizes German quality yet at the same time, through its positive impact increases Germany's ability to attract foreign direct investment. If a US company wants to produce a product with high quality for European market, there is a high probability that Germany will be considered when compared with other countries.

Finally, according to several authors (Johnson, Toledano, Strauss, and James, 2013, Mayer and Mucchielli 1999; Thomas, 2007; 2011), there is a powerful national competition to attract foreign investment, particularly, within the European Community. Dunning (1998) notes even a competition within the same 
country or region to attract FDI. According to Dunning (2009), different incentives are required to attract different types of investments. Similarly, the determinants of investment vary across different business types, one that led to the export of natural resources put less emphasis on the local market scale.

\section{Determinants of FDI}

Shaver (1998) identified several elements which impact the choice of US foreign direct investment location. These factors include: the state (position) of the coastal part, the low level of trade unions, and fewer legal restrictions, lower levels of economic activity, taxes and subsidy of international activities. A study of foreign direct investment in USA ascertained that a presence of other Japanese companies in the country will attract other Japanese firms to invest (Kotabe, 1993). Contrary to prior studies Blonigen (2005) suggests that the tax is an insignificant determinant of FDI. The institution quality, especially in less developed countries is considered to be an important determinant. Weak legal protection and increased country risk (corruption, land costs, etc.) is another important determinant (Amewokunu, 2009). In addition, the author mentions direct relationship between weak institutions and poor infrastructure along with reduced profitability. Other key elements are tariff barriers and the existence of foreign subsidiaries which create an export substation effect. Clusters also play a key role in attracting FDI. Cooperation of various companies which form business groups within the same industry generates various advantages, such as information exchange and the reduction of implementation and operation. This phenomenon can be linked with the mimicry concept explored Kotabe (1993).

\begin{tabular}{|c|c|c|}
\hline Isomorphic pressures & \multicolumn{2}{|c|}{ Levels of analysis } \\
\hline & Country & Enterprise \\
\hline Coercive & $\begin{array}{l}\text { Laws constraining, ownership } \\
\text { between country transfers } \\
\text { and operational control }\end{array}$ & $\begin{array}{l}\text { MNE rules mandating } \\
\text { organizational practices }\end{array}$ \\
\hline Mimetic & $\begin{array}{l}\text { Imitation of successful } \\
\text { country entrants }\end{array}$ & $\begin{array}{l}\text { Imitation of MNE siblings and } \\
\text { previous entries }\end{array}$ \\
\hline Normative & $\begin{array}{l}\text { Cultural expectations within } \\
\text { host country }\end{array}$ & $\begin{array}{l}\text { MNE control mechanisms and } \\
\text { shared beliefs }\end{array}$ \\
\hline
\end{tabular}

Figure 3-1 Determinants of FDI by isomorphic pressures adopted from Francis and Zheng (2009) 
Francis and Zheng (2009) identified nine levels of pressure called isomorphic pressure (Figure 1), which may lead to the selection of foreign direct investment. These pressure levels can be mandatory or regulatory and imitate the host country, industry or company. It is also important to note that foreign direct investment can occur in the context of relocation activities. On this issue, Birkinshaw, Braunerhjelm, Holm and Terjesen (2006) identified several factors which affect the relocation of the corporate headquarters and influence in attracting FDI. According to the authors, creating an attractive place is based on two main factors, namely industrial agglomeration and creating a favorable business environment. The author explores the characteristics of the different elements that enable a favorable business environment, including the level of competition in the industry and among competitors, the presence of a quality relationship between policies and government policymakers and also business providers close to the financial sector (banks and investors).

\section{Discussion}

The Dual Perspective on FDI attraction phenomenon considers two main factors that are multinationals and host location. On the one hand, the government is under pressure to achieve significant objectives such as economic development and job creation. A way to achieve these goals is to attract foreign direct investment. Therefore, the government can focus on strategy formation factors that are conducive to attracting foreign direct investment. Firstly, a business environment must be welcoming and favorable for FDI. In order to achieve this goal the government can engage in various marketing activities, trying to improve the country's or city's image. Multinationals have also been encouraged to take advantage of foreign direct investment in foreign markets as a means of implementing various pressure levels. Finally, meetings of government leaders and investment firms can facilitate the involvement of a third actor. In fact, it is often attractive for investment and development institutions to attract foreign direct investment. In this way the development of contacts between multinational companies and home environment of local government which forms a strategy is ensured.

In all countries, foreign direct investment (FDI) is recognized as a significant factor for adding value to the economies and is affiliated with companies which depend on multinationals to invest in order to achieve the objectives of economic growth. For all world cities to attract inflows of foreign direct investment, government officials on all levels and relevant departments should make every effort to encourage local residents to attract investors. Foreigners hoping to settle in the national companies are not enough to attain sufficient levels of FDI. In addition, the details of the company website should communicate attractive features of the city or country who wishes to attract businesses. Consequently, this would enable companies to attain a advantageous international position and make effective investment decisions in countries around the world. In this context, a number of theories and methods have been developed and information has been provided on the process of internationalization of companies and businesses. For instance, firm experience, reducing the time from the perspective of psychological processes and learning functions are all relevant 
factors (Casillas and Acedo, 2013; Johansson and Vahlne, 1977; Johnson and Wiedersheim Paul, 1975; Kogut, 1988; Vahlne, Ivarsson, and Johnson, 2011). Another theory which takes an analytical approach in explaining FDI is the resource-based theory. It focuses on financing of international business development and resource management (Mutinelli and Piscitello, 1998 ). Finally, the behavioral approach of competitors in the enterprise is also relevant (Aussilloux, 1997). This means that the attractiveness of the strategy to utilized to attract foreign direct investment should be considered. When forming a strategy for attracting FDI all these theories should be applied in order to take the necessary steps to meet the requirements and conditions of the strategic relationship position which can help resource mobilization and national economies. In some countries policies and strategies for FDI attainment are clearly defined and are aimed to promote the establishment of a secure and effective system. The most effective strategy chosen by the country consists of qualification stage, where company that fulfills the requirements in terms of technology quality and technical features, and capital. Next in the stand phase all useful and necessary measures to promote the realization of the next stage occur followed by the win stage where the contractor is hired that is seen as being the most effective in providing the service. For this reason, it is necessary to have all the information on net investment provided, and sufficient staff available at any time to comply with the additional information requirements needed. In some places, the same information is found in a dozen languages of the world. They provide information on all areas and attractive investment conditions. Moreover, the resources of investors under the accompaniment are available, and its purpose is to make the investment in country's interests. The country offers to want to invest in exploration in order to allow the availability of resources and sufficient conditions for the validity of the investment framework which could guide the company to the opportunity for all its businesses to be operating smoothly in regard to international activities. In this context, several million dollars are distributed yearly to vote by commercial banks to investors. In addition, as part of the law of attraction of foreign direct investment, and also adopting and publishing a legitimate exercise of activities carried out by companies or businesses. Inferring from the conducted review of the literature we suggest that companies can create opportunities for FDI attraction in different industries by providing relevant information sought by selected business leaders. These selected people who are also in the field must be able to attract potential investors to specific events along with wealthy investors. Next, adequate tools for investment should be identified or created. These tools can help support the analysis, in collaboration with companies from different sectors. Furthermore, business leaders should be encouraged and subsidized to participate in international influential seminars. Finally after investment service could be created. This program would provides a special way to establish an expanding network encompassing suppliers, professionals, workers and others, who need to contact and provide solutions, and discuss the problems that foreign investors are facing. 


\section{Conclusion}

In order to attract more investment countries need to generate a favorable investment climate. Reforms aimed at creating a climate for political decision-oriented investment play an important role in this regard. In addition to the investment climate being key to economic growth, it is also important an important determinant how globalization is affecting domestic customers. The specific circumstances and enforcement practices were cited in the articles. Furthermore the benefits of FDI were clearly illustrated. The innovation of this study is that it builds on previous research and synthesizes strategies designed to attract foreign direct investment. The findings suggest that government officials working in the scope of FDI should create and implement policies which are facilitating FDI. Together with the other determinants which the study identified a favorable environment for foreign direct investment can be created. We suggest a future study is conducted which would test the impact of these determinants and strategies on FDI in a specific context of a country, region or city.

\section{References}

- Amewokunu, Y., \& Su, Z. (2009). Repenser l'évaluation du risque-pays dans le contexte de la mondialisation. Management international/Gestiòn Internacional/International Management, 13(2), 35-52.

- Aussilloux, V. (1997). Investissements directs, tarifs douaniers et emplois: une modélisation en termes d'équilibre de Stackelberg. Commerce Nord-Sud, migration, délocalisation: les effets sur les salaires et l'emploi, Economica, 102-118.

- Bevan, A. A., \& Estrin, S. (2004). The determinants of foreign direct investment into European transition economies. Journal of Comparative Economics, 32(4), 775-787.

- Birkinshaw, J., Braunerhjelm, P., Holm, U., \& Terjesen, S. (2006). Why do some multinational corporations relocate their headquarters overseas? Strategic Management Journal, 277), 681-700.

- Blonigen, B. A. (2005). A review of the empirical literature on FDI determinants. Atlantic Economic Journal, 33(4), 383-403.

- Brossard, H. L. (1998). Information sources used by an organization during a complex decision process: an exploratory study. Industrial Marketing Management, 271), 41-50.

- Booth, M., Königer, J., \& Nunnenkamp, P. (2010). FDI promotion through bilateral investment treaties: more than a bit? Review of World Economics, 146(1), 147-177.

- Casillas, J. C., \& Acedo, F. J. (2013). Speed in the internationalization process of the firm. International Journal of Management Reviews, 15(1), 15-29.

- Dunning, J. H. (1998). Location and the multinational enterprise: a neglected factor? Journal of International Business Studies, 45-66. 
- Dunning, J. H. (2009). Location and the multinational enterprise: John Dunning's thoughts on receiving the Journal of International Business Studies 2008 Decade Award. Journal of International Business Studies, 4Q1), 20-34.

- Dunning, J. H. (2013). Multinationals, Technology \& Competitiveness (Vol. 13): Routledge.

- Francis, A. P. J., \& Zheng, A. P. C. (2009). An institutional perspective on foreign direct investment. Management International Review, 495), 565-583.

- Johanson, J., \& Vahlne, J.-E. (1977). The internationalization process of the firm-a model of knowledge development and increasing foreign market commitments. Journal of International Business Studies, 8(1), 23-32.

- Johanson, J., \& Wiedersheim-Paul, F. (1975). The internationalization of the firm-four swedish cases 1. Journal of Management Studies, 12(3), 305-323.

- Johnson, L., Toledano, P., Strauss, I., \& James, S. (2013). Background Paper on Investment Incentives: The good, the bad and the ugly: Assessing the costs, benefits and options for policy reform.

- Kalamova, M. M., \& Konrad, K. A. (2010). Nation Brands and Foreign Direct Investment*. Kyklos, 63(3), 400-431.

- Kogut, B. (1988). Joint ventures: Theoretical and empirical perspectives. Strategic Management Journal, 94), 319-332.

- Kotabe, M. (1993). The promotional roles of the state government and Japanese manufacturing direct investment in the United States. Journal of Business Research, 272), 131-146.

- Kumar, N. (1998). Technology generation and technology transfers in the world economy: recent trends and implications for developing countries. Science Technology \& Society, 3(2), 265-306.

- Kumar, N. (2009). Liberalisation, Foreign Direct Investment Flows and Development. Readings in Indian Agriculture and Industry, 465.

- Kumar, N., \& Siddharthan, N. S. (2013). Technology, Market Structure and Internationalization: Issues and Policies for Developing Countries. Routledge.

- Mayer, T., \& Mucchielli, J.-L. (1999). La localisation à l'étranger des entreprises multinationales. Une approche d'économie géographique hiérarchisée appliquée aux entreprise japonaises en Europe. Economie et statistique, 326(1), 159-176.

- McCann, P., \& Mudambi, R. (2004). The location behavior of the multinational enterprise: Some analytical issues. Growth and Change, 35(4), 491-524.

- Monaghan, S. (2012). Attraction and Retention of Foreign Direct Investment (FDI): The Role of Subnational Institutions in a Small, Highly Globalised Economy. Irish Journal of Management, 31(2).

- Mucchielli, J.-L. (1991). Alliances stratégiques et firmes multinationales: une nouvelle théorie pour de nouvelles formes de multinationalisation. Revue d'économie industrielle, 55(1), 118-134.

- Mucchielli, J.-L. (1998). Multinationales et mondialisation (Vol. 41): Éd. du Seuil. 
- Musolesi, A. (2006). Recherche, productivité et externalités internationales: une analyse économétrique sur données de panel pour un groupe de pays de l'OCDE: LEG, Laboratoire d'Economie et de Gestion, CNRS, Université de Bourgogne.

- Mutinelli, M., \& Piscitello, L. (1998). The entry mode choice of MNEs: an evolutionary approach. Research policy, 275), 491-506.

- Shaver, J. M. (1998). Do foreign-owned and US-owned establishments exhibit the same location pattern in US manufacturing industries? Journal of International Business Studies, 469-492.

- Sinanagic, M., Civic, B., \& Kamaric, A. (2012). Institutional marketing communications in role of attracting foreign direct investments to bosnia and herzegovina. Economic Review: Journal of Economics \& Business/Ekonomska Revija: Casopis za Ekonomiju i Biznis, 101).

- Thomas, K. P. (2007). Investment incentives: Growing use, uncertain benefits, uneven controls. Interntional Institute for Sustainable Development= Institut international du développement durable.

- Thomas, K. P. (2011). Regulating Investment Attraction: Canada's Code of Conduct on Incentives in a Comparative Context. Canadian Public Policy, 373), 343-357.

- Vahlne, J.-E., Ivarsson, I., \& Johanson, J. (2011). The tortuous road to globalization for Volvo's heavy truck business: Extending the scope of the Uppsala model. International Business Review, 2011), 114. 